\title{
Extraskeletal Myxoid Chondrosarcoma of Larynx
}

\author{
Ki Ju Cho ${ }^{1}$, Seong Chul Yeo ${ }^{1}$, Sung Jun Won ${ }^{1}$, and Seung Hoon Woo ${ }^{1,2}$ \\ ${ }^{1}$ Department of Otorhinolaryngology, ${ }^{2}$ Institute of Health Sciences, College of Medicine, Gyeongsang National University, Jinju, Korea
}

\section{후두에 발생한 골격외 점액성 연골육종}

조기주 ${ }^{1} \cdot$ 여성철 ${ }^{1} \cdot$ 원성준 $^{1} \cdot$ 우승훈 ${ }^{1,2}$

경상대학교 의과대학 이비인후과학교실, ${ }^{1}$ 건강과학원 ${ }^{2}$

\author{
Received August 13, 2015 \\ Revised September 16, 2015 \\ Accepted October 2, 2015 \\ Address for correspondence \\ Seung Hoon Woo, MD \\ Department of Otorhinolaryngology, \\ College of Medicine, \\ Gyeongsang National University, \\ 79 Gangnam-ro, Jinju 52727, Korea \\ Tel $+82-55-750-8173$ \\ Fax $+82-55-759-0613$ \\ E-mail lesaby@hanmail.net
}

Primary cartilaginous tumors of the laryngeal lesion are rare and it accounts for only $1 \%$ of laryngeal tumor pathology. They are most commonly located on the endolaryngeal surface of cricoid cartilage, and it is extremely rare to find them in vocal muscle lesion. In most cases, treatment of choice is based on surgical excision, and postoperative radiotherapy is typically recommended. We experienced a case of a 22 -year-old young woman without underlying disease, presenting extraskeletal myxoid chondrosarcoma of vocal cord, especially in the vocal muscle. The patient underwent mass excision through suspension laryngoscope and radiation therapy.

Korean J Otorhinolaryngol-Head Neck Surg 2016;59(7):527-31
서 론

연골육종(chondrosarcoma)은 유리질 연골(hyaline cartilage)의 증식에 따라, 서서히 자라는 악성 연골종양(malignant cartilaginous tumor)으로 대개 골반(pevis), 대퇴골(femur), 흥곽(ribcage), 상완골(humerus), 견갑골(scapula) 등에서 발생한다.

두경부에 발생하는 경우는 전체의 대략 10 20\% 정도이고 후두에 발생하는 경우는 극히 드물어 $1 \%$ 이하이다. ${ }^{1)}$ 후두에 서는 대개 윤상연골(cricoids cartilage)의 후측면에서 주로 기 원하며, 갑상연골(thyroid cartilage)이나 피열연골(arytenoid cartilage)에서는 드물게 발견되고, 성대근(vocalis muscle)에 서 발견되는 경우는 매우 드물다.1)

최근 저자들은 기저질환 전혀 없이 애성(hoarseness)을 주 소로 내원한 22세 젊은 여자 환자에서 후두, 특히 성대근(vocalis muscle)에 발생한 골격외 점액성 연골육종(extraskeletal myxoid chondrosarcoma) 1예를 경험하였기에 문헌고찰과 함께 보고하는 바이다.
증 례

22세 여자 환자가 2개월 전부터 발생한 애성을 주소로 내원 하였다. 환자는 고혈압, 당뇨병, 결핵 등의 질환을 않은 과거 력은 없었고, 흡연, 음주를 하지 않았으며 애성 이외에 호흡곤 란, 천명, 연하곤란, 체중감소 등의 증상이나 다른 불편감은 없 었다. 후두경 검사에서 좌측 성대 중간부위에 충혈(hyperemia) 된 소견이 관찰되었고, 상피세포 밑층에 표면이 매끈한 낭종 병변(cystic lesion)이 관찰되었다(Fig. 1). 경부에서 비정상적 인 림프절은 촉지되지 않았으며 일반 혈액검사, 소변검사, 심 전도, 흥부 X-ray 검사에서는 특이소견이 없었다.

본 환자는 젊은 나이이고, 기저질환 없으며, 평소 말을 많이 하는 직업도 아니었기 때문에 우선 후두 낭종 의심 하에 경과 관찰하기로 하였다. 1 개월이 지난 후에도 환자의 증상은 호전 되지 않고, 병변의 변화가 보이지 않아 경부 전산화단층촬영 검사를 시행하였다. 경부 전산화단층촬영 검사에서 좌측 성 대부위에 경계가 좋은 약 $1.2 \times 1.5 \mathrm{~cm}$ 크기의 종물이 관찰되 었고, 종물 내부에는 약하게 조영 증강 되어 있는 소견이었다 (Fig. 2). 


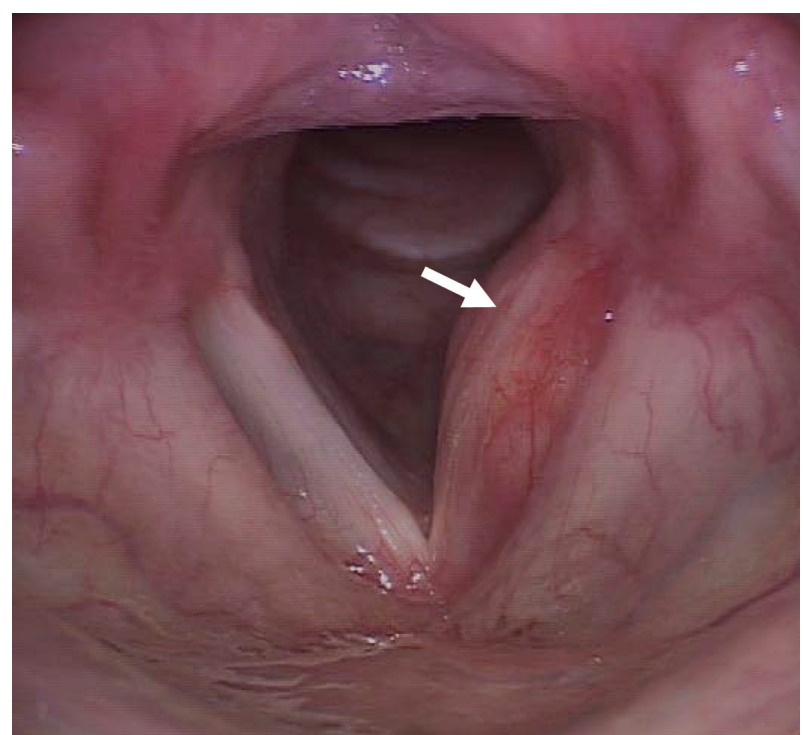

Fig. 1. Preoperative endoscopic finding; about $1.2 \times 1.5 \mathrm{~cm}$ sized mass with smooth surface located in left true vocal cord (arrow).
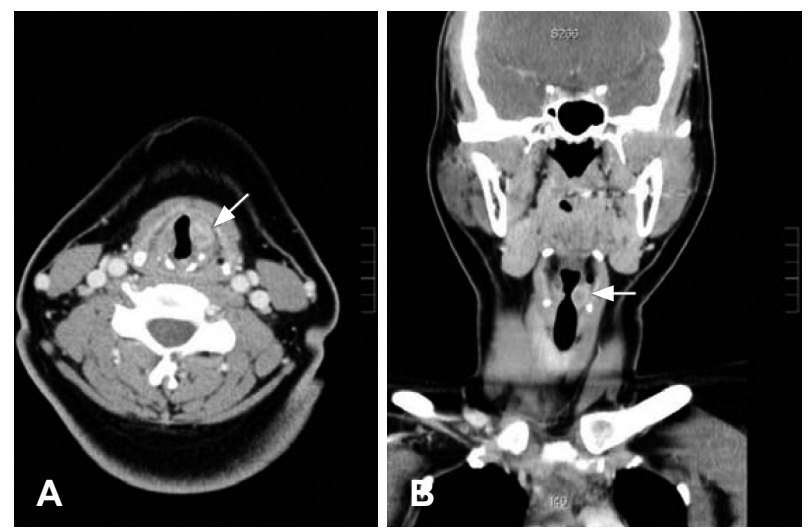

Fig. 2. Preoperative coronal pharynx CT shows well defined mass margin, central lesion mild enhancement (arrow) (A). Preoperative axial pharynx ECT (arrow) (B).

종물에 대한 병리학적인 확인이 필요하여 현수 후두경하 조 직검사를 시행하고 향후 치료방향을 결정하기로 하였다. 조 직검사는 전신 마취하에 시행하였고, 현수 후두경을 이용해 성대 부위를 노출하였다. 이후 좌측 성대 부위의 상부 병변 부위 점막에 절개를 가하여 종물을 확인하였다. 종물은 표면 이 매끈하고 비교적 둥근 형태의 흰색을 띠는 양상을 보였으 며, 일괄로 제거하기 어려워 cutting forcep을 이용하여 제거 하는 과정 중에 쉽게 부서지는 해면골 양상의 조직들이 적출 되었다. 본 종물은 성대 근육인 성대근(vocal muscle) 안에만 국한되어 있었으며, 주변의 갑상연골이나 윤상연골과는 어떤 연결도 가지고 있지 않은 단독병변으로 확인되었다(Fig. 3).

수술 중 적출된 조직으로 동결절편검사를 시행하였고, 저등 도의 악성종양의 가능성과 양성종양에서 결정할 수 없는 결 과를 얻었다. 따라서 후두 현수경 소견에서 관찰되는 병변을
가능한 완전히 제거를 한 후, 절개한 성대 점막부위를 봉합 한 후 수술을 마쳤다.

수술 후 병리 소견상 연골성 조직이 관찰되었지만, 양성 연 골종(benign chondroma)의 경우보다는 연골(cartilage) 구 조가 명확하게 보이지 않고, 상대적으로 분화가 잘 되어 있지 않으며, 세포충실성(cellularity)과 세포분열(mitosis)하는 세 포가 많이 관찰되었다. 또한 연골조직 주변으로 푸른빛을 띠 는 호염기성(basophilic)의 점액성 기질(myxoid matrix)이 관 찰되었다(Fig. 4). 그리고 면역조직화학적 검사에서 상피세포 (epithelial cell)에 결합하는 cytokeratin, p63에 전혀 염색된 소 견이 관찰되지 않았고, 세포골격(cytoskeleton) 표지자(marker) 인 vimentin에 양성으로 나타나서 간엽성(mesenchymal) 세 포에서 유래된 암종임을 확인하여 골격외 점액성 연골육종 (extraskeletal myxoid chondrosarcoma)을 진단할 수 있었 다(Fig. 5). 환자는 수술 후 특별한 합병증 없이 퇴원하였고, 후두 내시경 검사에서 양측 성대마비의 소견은 없었다. 이후 환자는 방사선치료를 받았고, 수술 후 6개월째 재발 소견이 관찰이 되지 않았다. 수술 전에 비해 양호해진 음성 상태를 보이며, 경과 관찰 중이다.

\section{고 찰}

후두 연골육종은 전체 후두 종양의 $1 \%$ 미만이며, 악성종양 가운데 0.07 0.2\%를 차지하고 있다.) 1935 년 처음 보고된 후로 최근까지 약 600예 정도가 보고되었다. 대부분 윤상연 골(75\%)에서 기원하며 그 다음이 갑상연골(17\%)에서 기원한 경우이다. 피열연골, 후두개의 경우는 전체 증례의 $5 \%$ 미만 이다. 남녀 간 발생 빈도는 3:1 정도로 남자에게 많이 발생하 며, 호발연령은 50 70세이다. ${ }^{2)}$ 유발인자로는 국소적인 외상, 방사선조사, 흡연, Teflon 주입 등이 있다. ${ }^{1,3}$

병태생리(pathophysiology)는 정확하지 않지만, 만성염증 과 노화와 관련된 대사이상이 관여한다는 것도 보고되었고, 연골종(chondroma)의 허혈성 변화(ischemic change)가 연골 육종의 발생에 기여한다는 것도 밝혀졌다. 그러나 가장 중요한 것은 유리질 연골이 골화(ossification)된 소견이 많은 증례에 서 관찰되면서, 이 과정의 이상이 후두 연골 육종의 발생에 중 요한 기전임이 밝혀져 있다. ${ }^{4}$

임상증상은 종양의 위치, 크기, 진행양상에 따라 나타난 다. 애성은 가장 흔한 임상증상으로 약 $65 \%$ 의 환자에서 관 찰되며, 이외에 호흡곤란, 연하곤란, 기침 등이 있다. 성대마 비 증상도 보일 수 있으며 이는 종양의 직접적인 신경 침습보 다는 종양의 크기 때문에 성대의 움직임에 장애를 초래하기 때문으로 알려져 있다. ${ }^{5)}$ 

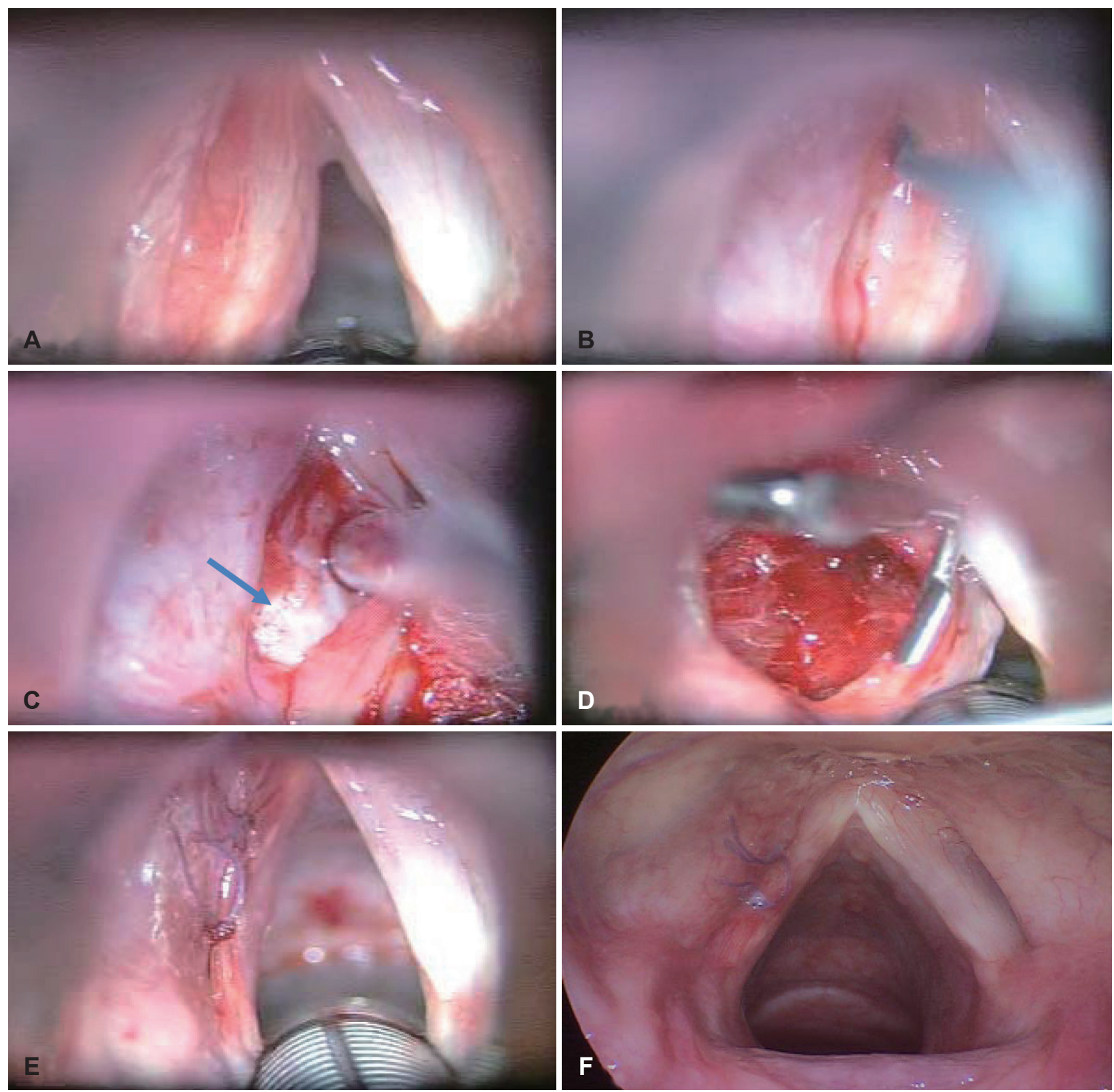

Fig. 3. Intraoperative field. Mass located in left true vocal cord (A). Exposure incision on burging site (B). Whitish round shape mass in vocal cord muscle layer (arrow) (C). Completely resected cancer (D). Sutured true vocal cord epithelial layer (E). Post operative 1 month view, well preserved true vocal cord epithelial layer (F).

영상의학적 특징은 다양한데, 전산화단층촬영에서는 종양 의 위치, 크기, 범위나 침습정도를 알 수 있으며, 주로 중간 정도의 조영 증강을 보이는 저밀도의 경계가 뚜렷한 종양의 특징을 보인다. 자기공명영상(MRI)에서는 종양의 침습 정도 와 주변 조직 간의 관계를 파악하는 데 더 유리하다. 이러한 것이 수술적 절제의 범위를 결정하는 데 중요한 정보가 된다. 하지만 영상의학적 방법으로 연골종과 저등도의 연골육종 을 구별하기는 쉽지 않다.1) 따라서, 조직검사를 통해 연골육 종의 조직학적 특징을 관찰하여 진단할 수 있는데, 최근에는 core needle biopsy를 통해 fine needle aspiration보다는 진
단율이 높으면서 suspension biopsy보다는 덜 침습적인 방법 을 이용한 사례가 발표된 바 있다.) 그러나 본 증례의 경우 22세의 젊은 여성이고 흡연과 외부 방사선 조사 등의 외부유 발요인이 전혀 없었기에 암종을 예측하기는 쉽지 않았다. 더 구나 성대근(vocalis muscle)에 병변이 위치하였기에 세침검 사나 중심생검은 시도하기가 어려웠다. 따라서 현수 후두경 하에 종물 제거를 목표로 수술을 시행하였고 암종으로 진단 되어 추가적으로 방사선치료를 시행하였다.

연골육종의 조직학적 진단기준은 세포학적 분화도에 따라 grade I, II, III로 분류된다. 저등급일수록 연골성 기질이나 

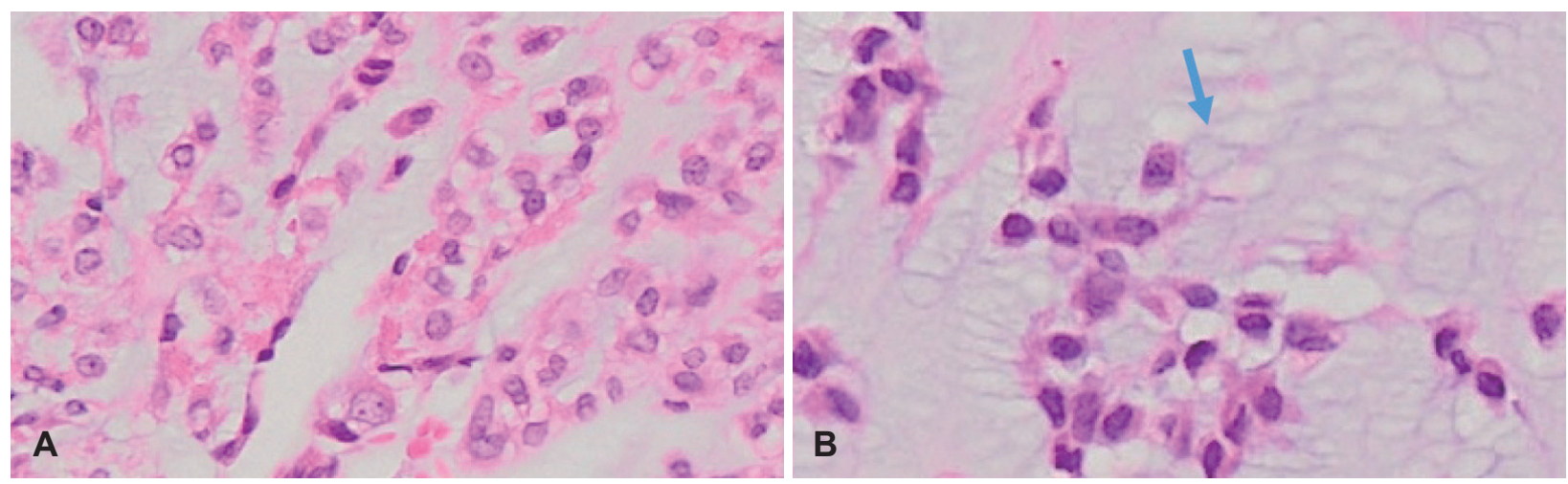

Fig. 4. Histologic findings. Chondrosarcoma showing pure hyaline cartilage differentiation, the cellularity and mitosis cells are increased $(H \& E$ stain, $\times 200)(A)$. Bluish myxoid stroma surrounding tumor cells (arrow) (H\&E stain, $\times 200)(B)$.
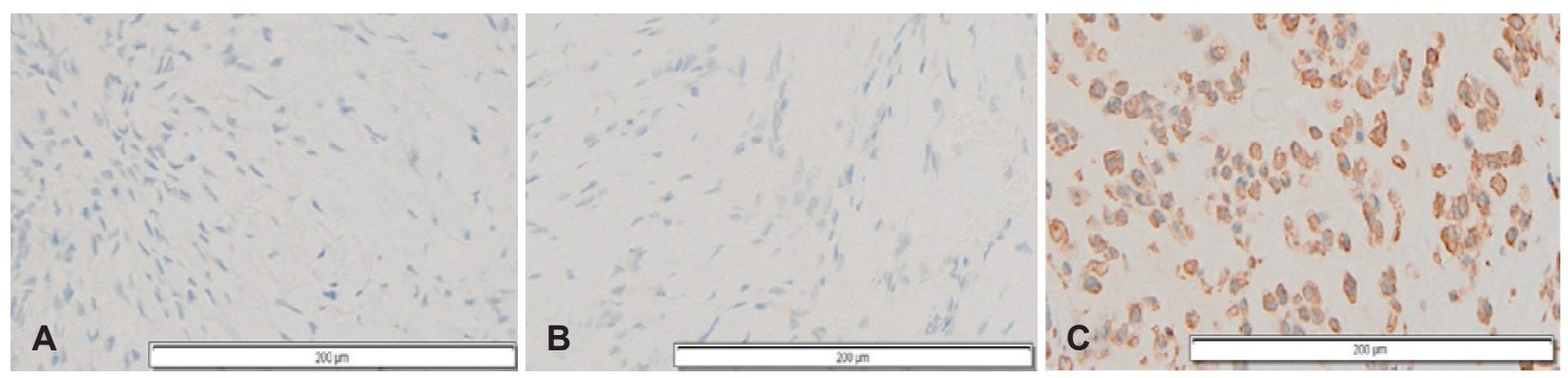

Fig. 5. Immunohistochemistry findings. Cytokeratin: negative $(\times 200)(A)$. p63: negative $(\times 200)(B)$. Vimentin: positive $(\times 200)(C)$.

소강(lacuna) 등을 잘 유지하고 있고, 세포분열은 거의 관찰 되지 않으며 분화도가 좋다. 그리고 등급이 높아질수록 소강 구조가 잘 유지되지 않고 핵, 세포질의 변화, 세포분열이 많 이 관찰된다. 연골육종의 변형으로 투명세포연골육종(clear cell chondrosarcoma), 점액성 연골육종(myxoid chondrosarcoma), 역분화성 연골육종(dedifferentiated chondrosarcoma), 그리고 간엽성 연골육종(mesenchymal chondrosarcoma)이 있다. 본 증례는 점액성 연골육종이었고, 이는 grade II에 해 당하며, 최종적으로 골격외 점액성 연골육종(extraskeletal myxoid chondrosarcoma)이 진단되었다. 골격외 연골육종은 비교적 잘 분화된 연골로 구성된 연부조직 종양으로 골격에 서 발생한 경우보다 상대적으로 덜 공격적인 양상을 보인다.)

치료는 수술적 절제가 주된 치료방법이며 병소의 광범위한 국소적 절제에서부터 후두전적출술에 이르기까지 다양하다. 종양의 절제 범위는 종양이 주변 조직으로 침습한 정도에 따 라 결정되며 윤상연골의 절반 이상을 침범한 종양은 후두적 출술이 최선의 치료방법이다. 연골육종의 재발이 늦게 나타 나고 전이율이 낮으므로 가능한 보존적 수술을 해야 하며 후 두전적출술은 분화도가 좋지 않은 종양, 재발한 종양, 그리고 보존적 수술로는 완전 절제가 힘든 종양에서 시행되어야 한 다는 의견이 지배적이다. 방사선치료는 종양의 절제가 불가능 하거나 분화도가 낮고 술 후 잔류 암종이 존재하는 경우에 이
용되고, 술 후 방사선 병합요법으로 주로 이용되고 있다. ${ }^{5,8)}$ 최 근 방사선치료의 효과가 있다는 보고가 있어, 본 증례의 환자 는 22세라는 연령대와 기대여명을 고려하여, 후두전적출술보 다는 보존적 수술로 종물을 제거하고 추가로 방사선치료를 시행하였다. ${ }^{9}$

수술 후 치료실패의 주된 원인은 국소재발이며 재발률은 $35 ~ 40 \%$ 사이로 보고되고 있으며, 종양의 불완전한 절제와 분 화도가 낮은 종양에서 재발의 가능성이 있는 것으로 보고되 고 있다. ${ }^{5)}$ 예후는 종양의 발생 부위와 침범 정도, 종양의 조 직학적 분화도, 종양의 완전절제 가능성 등에 의해 결정된다.

원격전이는 약 $10 \%$ 정도로 드문 편이며, 주로 폐로 전이가 많다. 두경부 연골육종의 5년 생존율은 grade I에서 90\%, grade II에서 $81 \%$, grade III에서 43\%로 보고되고 있다. 후 두 연골육종은 다른 부위에서 발생한 육종에 비하여 성장속 도가 느리고 덜 침습적이므로 다른 육종에 비해 생존율이 높 은 편이다. 하지만 후두 연골육종의 경우 첫 치료 후 20 30년 이 지난 후 재발이 생기는 것으로 알려져 있어 5년 생존율을 확인하는 것이 큰 의미가 없다. ${ }^{10)}$ 본 증례의 경우 수술 후 방사 선치료를 하였고, 재발 없이 경과 관찰 중이지만 향후 20 30 년 후에도 추적관찰이 필요하다.

또한, 드문 증례이기 때문에 각각의 치료법에 대한 비교 결 과는 찾아볼 수 없었다. 따라서 이러한 증례를 종합하여 연 
구를 하면 앞으로 적절한 치료의 방향을 잡는 데 도움이 될 수 있다는 것에서 이 증례의 의미를 찾을 수 있을 것이다.

\section{REFERENCES}

1) Oliveira JF, Branquinho FA, Monteiro AR, Portugal ME, Guimarães AM. Laryngeal chondrosarcoma--ten years of experience. Braz J Otorhinolaryngol 2014;80(4):354-8.

2) $\mathrm{Hu} R, \mathrm{Xu} \mathrm{W}$, Liu $\mathrm{H}$, Chen $\mathrm{X}$. Laryngeal chondrosarcoma of the arytenoid cartilage presenting as bilateral vocal fold immobility: a case report and literature review. J Voice 2014;28(1):129.e13-e17.

3) Okamoto $S$, Hisaoka M, Ishida $T$, Imamura $T$, Kanda $H$, Shimajiri $\mathrm{S}$, et al. Extraskeletal myxoid chondrosarcoma: a clinicopathologic, immunohistochemical, and molecular analysis of 18 cases. Hum Pathol 2001;32(10):1116-24.

4) De Cock M, Van Laer C, Vanwambeke K, Salgado R. Chondrosarcoma of the larynx: a report of two cases and a review of the literature. B-ENT 2006;2(1):21-6.
5) Thompson LD, Gannon FH. Chondrosarcoma of the larynx: a clinicopathologic study of 111 cases with a review of the literature. Am J Surg Pathol 2002;26(7):836-51.

6) Miyamaru S, Haba K. Laryngeal chondrosarcoma diagnosed by core-needle biopsy. Am J Otolaryngol 2014;35(4):535-7.

7) Babarovic E, Zamolo G, Kujundzic M, Cvjetkovic N. Myxoid chondrosarcoma of the cricoid cartilage. Indian J Pathol Microbiol 2012;55(3):424-6.

8) Park SY, Kim SC, Ryu JW, Chang CS. Laryngeal chondrosarcoma arising from the cricoid cartilage. Korean J Otolaryngol-Head Neck Surg 2003;46(9):790-3.

9) Dailiana T, Nomikos P, Kapranos N, Thanos L, Papathanasiou M, Alexopoulou E, et al. Chondrosarcoma of the larynx: treatment with radiotherapy. Skeletal Radiol 2002;31(9):547-9.

10) Chang JW, Shin HA, Jung HM, Choi EC. A case of primary chondrosarcoma of the cricoid cartilage. Korean J OtorhinolaryngolHead Neck Surg 2010;53(6):378-82. 